\title{
THE ROLE OF FOSTER CAREGIVERS IN THE EFFECTIVENESS OF ONLINE LEARNING IN PESANTREN
}

\author{
Muhammad Mushfi El Iq Bali, Noer Holilah \\ ${ }^{1,2}$ Nurul Jadid University, Probolinggo, Indonesia \\ email: mushfieliqbali8@gmail.com
}

\begin{abstract}
ABSTRACK
The role of foster care in the pesantren is a solution for the pesantren in optimizing all work programs and activities of the pesantren, especially in online learning that is carried out in the pesantren. This study is more focused on the guardianship system of Madrasah Ibtidaiyah students under the age of 11 who carry out online learning in Islamic boarding schools. This research uses a qualitative approach with the type of case study at the Pondok Pesantren Nurul Jadid, especially in the Fathimatuzzahro area. The results showed that in online learning carried out in Islamic boarding schools, foster caregivers have several roles that help make online learning more effective. First, the foster caregivers act as badals of the parents of their foster children. Second, the foster caregivers act as badal for the teacher/teacher of their foster children. Third, foster caregivers act as facilitators for their foster children. Fourth, foster caregivers become uswah for students who become their foster children. It is hoped that this will help the pesantren to streamline and maximize online learning at the pesantren to achieve the educational goals expected by all parties.
\end{abstract}

\begin{abstract}
ABSTRAK
Peran wali asuh di pesantren merupakan suatu solusi dari pesantren dalam mengoptimalkan segala program kerja dan kegiatan kepesantrenan, khususnya dalam pembelajaran daring yang dilaksanakan di pesantren. Studi ini lebih difokuskan pada sistem kewaliasuhan siswa Madrasah Ibtidaiyah di bawah umur 11 tahun yang melaksanakan pembelajaran daring di pesantren. Penelitian ini menggunakan pendekatan kualitatif dengan jenis studi kasus di Pondok Pesantren Nurul Jadid khususnya di Wilayah Fathimatuzzahro'. Hasil penelitian menunjukan bahwa dalam pembelajaran daring yang dilaksanakan di pesantren, wali asuh memiliki beberapa peran yang membantu mengefektifkan pembelajaran daring tersebut. Pertama, wali asuh berperan sebagai badal dari orang tua anak asuhnya. Kedua, wali asuh berperan sebagai badal dari guru/pengajar anak asuhnya. Ketiga, wali asuh berperan sebagai fasilitator untuk anak asuhnya. Keempat, wali asuh menjadi uswah bagi santri yang menjadi anak asuhnya. Hal tersebut diupayakan mampu membantu pesantren dalam mengefektifkan dan memaksimalkan pembelajaran daring di pesantren sehingga tercapai tujuan pendidikan yang diharapkan oleh semua pihak.
\end{abstract}

Keyword: foster caregiver, online learning, pesantren.

\section{A. INTRODUCTION}

Education is a field that constantly gets demands to be carried out wherever and whenever it is. This has become a mindset that is embedded to its roots in various circles, both from the subject and object of education (Wahid et al. 2020). From these thoughts, it is undeniable that education is the answer as the main factor for improving the quality of human resources that can open thoughts in the future. In its origin, 3 aspects are goals in 
an education, namely cognitive, affective and psychomotor aspects. All three can be obtained through a lesson led by a teacher and followed by students. Learning is a difficult element apart from education, because learning is none other than the main element or evidence of the implementation of an education (Rozi et al. 2020).

Until now, the world of education is still being tested in all aspects, especially in the learning system. With the existence of Covid-19, the government has faced challenges to continue implementing education while all sectors are being announced temporarily. Responding to this matter, the government is responsive to its role in preventing Covid-19, as evidenced by the issuance of a circular ordering all activities carried out indoors and outdoors in all sectors to be temporarily postponed to reduce the spread of Covid-19, especially in the education sector.

In response to this, many educational institutions have responded quickly by issuing instructions for the prevention of Covid-19, namely continuing to carry out learning activities but carried out without face-to-face learning with online learning. Given that information and communication technology has now reached the era of digital revolution, it is possible if an education is carried out using technology (Muali et al. 2018). The ease of access to technology has been used by many teachers whose aim is to improve the quality of education. In this case, Keengwe $\&$ Georgina in their research explained that technological developments can provide changes to the implementation of teaching and learning (Khusniyah and Hakim 2019).

Judging from the circular issued by the Minister of Education and Culture of the Republic of Indonesia Number 4 of 2020 regarding the implementation of education policies during the pandemic period, that the teaching and learning process is carried out in each home through online/online learning (Dewi 2020). Seeing this situation, it is a demand for all educational institutions in Indonesia to carry out online-based learning, including educational institutions under the auspices of pesantren.

As is well known, one of Indonesia's original cultural assets is the pesantren which can be said to be the oldest Islamic educational institution which is a place to educate, guide, foster nurturing so that they can become faithful and devoted people, with noble character (akhlaq al-karimah), and able to master science and technology so that children can develop good potential in themselves (Fawaid and Hasanah 2020). 
Meanwhile, in a study it was explained that pesantren had special characteristics, both from the kiai as the main figure, the santri as the object, the curriculum, tradition and the mosque as the center of its various activities. These various characteristics make pesantren remain visible and not left behind, even though many formal education systems with various systems and their strengths are growing in this country. This is because pesantren are supported by educational methods that are not only aimed at transferring knowledge alone, but also improving and enhancing morale, instilling, training and teaching good and praiseworthy morals, and preparing students to be able to live simply and independently with conditions a clean heart (Bali 2017). Pesantren are also a means of appreciating values embedded in spirituality and humanity and enhancing human morals. Educational activities in pesantren are not only limited to the delivery of knowledge but also involve efforts to instill attitudes and values to students who are learning.

Pesantren is a place for students to learn from various levels of social life that are gathered in a community called a hostel. Dormitory is a place for students to live their daily life as a household life and life in society. They are required to organize themselves and enrich their religious knowledge, especially morals and morals. During the current pandemic, it is very influential on the systematics of education in pesantren. Students are forced to learn from home by doing a pattern of distance learning (remote teaching) which is based on the internet/online network (Yoga Purandina and Astra Winaya 2020).

With this abnormality, pesantren are required to be able to anticipate and maintain the continuity of education by continuing to carry out online learning as is done by outside schools in general. In addition to these demands, pesantren must also be able to become a means for students to carry out their learning activities. Given that an education is not only limited to transfer of knowledge, but also needs education and guidance on the character and morality of students. If in a school in a normal state there are teachers and parents as their educators and mentors, the pesantren has administrators who are their guardians in their daily lives at the pesantren, especially when studying. As stated by Fawaid and Hasanah in their research, the pesantren environment becomes an environment that is very important for students in shaping character (Fawaid and Hasanah 2020). Thus, the existing parenting style in the pesantren 
must have a fairly good system in directing and guiding the students.

Behind an education system, it is inseparable from the way parents educate and raises children. Parents' upbringing in nurturing for, caring for, treating for and educating children is a very influencing thing for children's development and growth (Islam et al. 2018). Parents' consistency in caring for and guiding their children is needed until they reach adolescence (Oktavia et al. 2019). This is the positive side of a pesantren, given that online learning is mostly limited to giving assignments. In pesantren, the role of parents is taken over by all the administrators who will always guide and accompany the development of students, especially in terms of educational development.

Regarding the discussion of parenting styles in pesantren, each pesantren must have its own system of foster caregivers. One of the pesantren that applies the guardianship system is the Pondok Pesantren Nurul Jadid which is located in Paiton sub-district, Probolinggo district. Pondok Pesantren Nurul Jadid has a program known as guardianship. This foster care program emerged as a characteristic inherent in Pondok Pesantren Nurul Jadid in handling and fostering quite a number of santri (Fawaid and Hasanah 2020). In a study, it was explained that the foster caregiver is a committee coordinated by the head of the Guidance and Counseling section who is in charge of the spiritual and emotional coaching of several students. And for the emotional development of students, it is nurturing and fostering the character building of the students. In addition, foster caregivers have duties like parents to their children, so their existence plays a central role in the effectiveness of students' activities, from spiritual to emotional activities (Ilmy, Wahid, and Muali 2018).

In its application, foster caregivers are required to be able to foster the emotional of students, namely by nurturing and fostering the character formation of students and being counsellors for students who are less disciplined in obeying pesantren regulations, especially in online schools within the pesantren. In addition, foster caregivers have the same exact duties as parents to their children and teachers to students. So the existence of foster care plays a central role for the effectiveness of santri education, especially ineffectiveness during online learning, from teaching activities to educational ones, from things that need to be educated to things that need to be uswah. 
With this foster care, pesantren are expected to be able to change the essence of online learning, which was initially limited to knowledge transfer and assignment alone into an effective teaching and education system, not only aimed at the students' cognitive but also on the affective and psychomotor of the students (K. Rahman et al. 2019). It is also hoped that this will increase the independence of the santri, which has basically become a characteristic that has been passed down from generation to generation in a pesantren.

From this, this research focuses on the parenting style carried out by foster caregivers for the continuity of online learning in pesantren. Given the all-round pesantren both in terms of facilities and places. And to see the effectiveness of this online learning for the sustainability of the education system in pesantren. Therefore, it needs to be researched and studied more deeply.

\section{B. LITERATURE REVIEW}

\section{Education in Pesantren}

Education is defined as a process with certain methods and strategies aimed at gaining knowledge, understanding, and how to behave according to needs. In a broader sense, education is the stages in developing individual abilities and behaviour, it is also a process of using almost all life experiences.

Education is a continuous process of continuity with elements of teaching, training, guidance and leadership who have a fulcrum for the transfer of various knowledge, values both religion and culture as well as useful skills to be applied by individuals (teachers or educators) to individuals who be the object of that education. In fact, education refers to humans as the main object in the educational process. Education is an urgent substance to achieve a perfect life for humans. It becomes the principle in fostering knowledge in shaping a more dynamic and educated self and society from a physical and spiritual perspective (Anisah Bahyah Ahmad 2006).

Education is more than just teaching, which is a process of knowledge transfer, value transformation, and personality formation with all the aspects it includes. This is different from teaching which is oriented more towards the formation of specialists or certain fields, therefore the attention and interest are more technical in nature (Nurkholis 2013). It can be understood that education is a package of teaching that has a more specific meaning. 
The element of education, more precisely when the learning process takes place, becomes the main element when education occurs. Learning is a complex process that involves a person physically and mentally throughout his life. It is called learning because there are interaction and communication between a person and their environment. Therefore, learning can happen anytime and anywhere. One of the characteristics of a person who is said to have experienced the learning process is a change in the individual both in behaviour, knowledge, talents/skills, and attitudes. There are two important things that are owned by education, namely the thinking aspect (cognitive) and the feeling aspect (affective). An example is, when we want to know about something, what happens is not only the thought process that is carried out but also there are elements related to feelings such as enthusiasm, liking and others. According to Ki Hajar Dewantara, the substance of education is to liberate humans and according to Drikarya, to humanize humans. This shows that experts also assess education that does not only focus on cognitive aspects but has a broader scope than what is commonly known (A. Rahman and Dkk 2020).
The most important thing in education is to realize its deepest meaning which is a systematic planning process so that the learning and learning process can be optimized. The formation of the learning and learning process is expected to develop the potential according to their talents and interests as well as their activeness in the development. Positive things will happen if the potential of students develops well, then all aspects which are the goals of education can be achieved both in religious spiritual strength, self-control, better personality, honed intelligence, noble character, and being able to have good skills. needed for himself others. In another sense, education is a planned effort to realize the growth and development of a child's body (physical) as well as those of a spiritual nature such as character (inner strength, character) and mind (intellect) (Sugiyono et al. 2014).

The concept of education according to K.H. Abdullah bin Nuh, namely the realization of an individual who has virtue and can devote himself to Allah in any educational activity they want and demand for himself to be useful for other individuals who do not see in terms of time and place. The meaning of the concept of Islamic education is everything that is made to the Prophet Sallallahu alaihi 
wasallam without having to be left behind in technological developments and times both in modern methods, systems and facilities (Munif and Aisah 2020). From this concept, the education in question is more specific to Islamic education which is more devoted to Salafi education but is able to accommodate new things that are happening at this time.

Seeing some of the definitions of education, basically, it is in line with the concept of education applied in pesantren. Given that pesantren are Islamic educational institutions that have existed since ancient times (the oldest) of other educational institutions in Indonesia, pesantren have important points in education and have concrete learning like education in general. It needs to be further understood that pesantren is an educational institution that does not only dominate the cognitive aspects but also dominates the affective aspects it gets not only through learning in schools. Because pesantren itself is a boarding educational institution, the habits of students can be monitored continuously for 24 hours (Bali and Susilowati 2019). Pesantren is a typical Indonesian educational institution that must be preserved, which has been trusted by many people to produce individuals who are not only intelligent but also have good morality.

The dominance of the affective aspect proves that the world in pesantren is closer to the meaning of education in its origin. The real purpose of education is that there is a change in behaviour towards students who become the object of education itself. Historically, the capacity of pesantren as religious institutions is capable of realizing a religious order of human life, with a fundamental and deep understanding of Islam. This manifestation can be proven through the learning system and process that takes place in the world of pesantren, namely the implementation of various scientific transfer processes to the students (Bali and Fadli 2019).

The world of pesantren is an area that can be said to be the second home for those who occupy it after their home. Pesantren is a place for students to learn from various different levels of social life that are gathered in a community called a hostel. A dormitory is a place for students to live their daily life as a household life and life in society. They are required to organize themselves and enrich their religious knowledge, especially morals and/or morality (Ilmy, Wahid, and Muali 2018).

The world of pesantren has its own uniqueness in it, Dhofier stated that the 
basic elements that make up the boarding school institutions are Kiai, students, mosques, dormitories and the yellow book (Zamroni et al. 2020). Pesantren is also an Islamic education and teaching institution in which there are interaction and communication between the Kiai or Ustadz as teachers/teachers and the students as students. This element can only be found in pesantren education institutions, it cannot be found in outside educational institutions in general. Therefore, education in the world of pesantren will feel like education in one's own home, considering that all elements become one, such as dormitories and mosques as places of worship.

Arifin explained that pesantren is an Islamic religious education institution that grows and is recognized by the surrounding community, with a boarding system (complex) in which santri receive education through the recitation system or madrasah which is fully under the leadership of the kyai with characteristics that are charismatic and independent in all respects (Lubis 2018). This proves that independence in a pesantren is able to revive the attitudes of the santri who are usually wrapped in laziness.

Another thing that makes the main difference in pesantren is uswah and prayer from kyai and teachers. It is common knowledge that human morality derives more from what they see than from what they learn. Imam Al-Ghazali explains in his book Bidayatul Hidayah as follows:

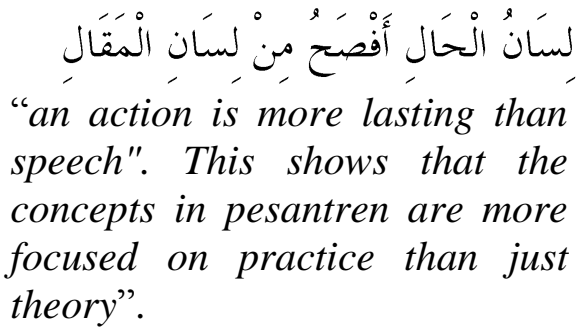

The maqolah explains that not everything obtained through theory can be easily applied by humans. The majority of them put into practice what they learn through the morals and attitudes of people they respect rather than just a word of mouth. Because considering that the human mindset is more dominant in visuals than just audio (something that is heard), it is not surprising that they value what they see more. Like a child, if told something they have to do, they will only be heard, unlike young children who are immediately given an example of an action, they will easily follow what they see. This proves that in education it is not enough to just race on the theory in the classroom, but also requires direct practice in the field. In this case, the pesantren is superior because it remembers the place where the students return is the dormitory that is still inside the pesantren so that it is easy to control. 


\section{Online Learning in Pesantren}

Online learning is one proof of the progress of the digital revolution era that is happening today. As stated by Mashudi in his research, Islamic education is now faced with the challenges of modern human life. Specifically, it should be directed to the changing needs of modern society. A new paradigm is needed to face new demands. If the new challenges are faced by using the old paradigm, then all efforts undertaken will meet the challenges of the changing times, either on the side of the concept, curriculum and the quality of human resources, institutions and organizations. Then, it could be relevant to community changes (Mashudi 2020). From these quotes, it is explained that the challenge of education, especially Islamic education, today is modern humans that lead to changes in modern society. A new paradigm is needed to face new demands. If the new paradigm is faced with the old one, the efforts that have been made will fail. Therefore, Islamic education must be designed to be able to meet the challenges of changing times, both in terms of concept, curriculum, quality of human resources, institutions and organizations.

The changing times that are so visible are seen from the technological aspects, both information and communication technology. The current technological system, which empirically tries to provide some solutions to human anxiety. Its presence provides an effort to make human life simpler, unravel complexity, facilitate access to knowledge, shorten how to work, and be efficient. So research and development is the main key in technological systems (A. Rahman and Dkk 2020). Seeing the development of this technology, if we relate it to the current situation, it will be a special convenience, especially in terms of education. Given the current situation where it is not possible to carry out education, as usual, the important solution is to take advantage of technology.

The application of educational transformation is a very appropriate choice in developing science and technology today because the international world is also constantly changing from the industrialization era to the information era. Changes that occur in society also require changes in the education system that we implement. System changes will be able to affect the system and joints of education. Thus, with the development of technology, the education system will also develop (Nurkholis 2013). This will affect several things related to the technology itself as an aspect that is at the centre of this transformation. Not only in information 
technology but also in communication technology.

Information and communication technology has an important role in the current and future pulse of activity, one of which is in the educational element. It is well understood that the development of the information and communication technology sector is one of the products that changes according to the present era to offer new things for education. One of the advantages possessed by modern information technology is that it can carry out teaching and learning activities without the presence of teachers and students. This means that students can study at different periods and locations, as well as make long-distance interactions with teachers (Bali 2019). At this time, distance learning education is often referred to as online learning.

Online learning is learning that uses internet networks with connectivity, accessibility, flexibility, and the ability to generate various types of learning interactions. Online learning is learning that is able to bring together subjects and objects in education to carry out the learning process with the help of the internet. There are many advantages of using information and communication technology in the implementation of online learning, including that it is not bound by time and space (Sadikin and Hamidah 2020).

Online learning is the use of internet networks in the learning process. With online learning, students have the flexibility to study time, can study anytime and anywhere. Students can interact with the teacher using several applications such as telephone or live chat, WhatsApp groups, classroom zoom or via video conference. This learning is an educational innovation to answer the challenges of the availability of varied learning resources. The success of a model or learning media depends on the characteristics of the students. But what is certain to be done is assigning tasks through monitoring mentoring by the teacher through WhatsApp groups so that children learn (Dewi 2020).

Online learning also has the advantage of being able to foster independent learning. The use of online applications can increase independence in learning. Another opinion states that online learning is more student-centred, which causes them to be able to create responsibility and autonomy in learning (learning autonomy). Learning online requires students to prepare their learning, evaluate, organize and simultaneously maintain motivation in 
learning, and can increase student interest. Online learning has special challenges, the location of students and teachers who are separate when carrying out learning causes the teacher not to be able to directly supervise the activities of students during the learning process. There is no guarantee that students listen to reviews from the teacher. Students will often fantasize about online learning than when learning face-toface. Therefore it is suggested that online learning should be held in a short time considering that students find it difficult to maintain their concentration if online learning is carried out for more than one hour.

Doing online learning activities is not a difficult thing to do for the world of outside education in general, even online learning is a learning process that is fairly instant but able to embrace all elements in education, even though there are pros and cons between one opinion and one opinion other. Unlike the case with the world of education in pesantren which can be said to be a world (part) in which it is far from easy to do things that are considered foreign to be implemented in the pesantren. This is a new thing that becomes a challenge for education in pesantren.

Pesantren is a unique and sustainable educational institution that has been trusted to produce students who are not only smart but also have good morality. Pesantren education teaches manners, behavioural traits, character and good morals through habituation in everyday life (Bali and Susilowati 2019). Pesantren is an Islamic educational institution that is closely related to very high discipline.

Online learning applied in pesantren is slightly different from its application outside the pesantren. Given that the pesantren is thick with its culture from generation to generation, this is somewhat contradicting the state of education carried out by an online system. In essence, this is not the main obstacle in doing online learning as is currently happening.

Zamakhsyari Dhofir in his research on pesantren traditions found that pesantren had a unique and unique tradition compared to educational institutions outside of pesantren (Bali 2017). As previously explained, the tradition that has developed in pesantren, especially in the field of education, is that it places more emphasis on the learning process itself, not on the results. The development of attitudes and changes in the character of students in their daily lives are the answers to the success of this education in the pesantren. In online learning, which is 
empirically limited to assigning tasks and controlling learning or not, this is the opposite of the concept of the pesantren itself, therefore pesantren has its system to carry out what has become the demands of the times with the culture in the pesantren. Because considering in this digital era 4.0, pesantren is an effective place to shape the character of students.

Looking at the positive side, online learning can be a supporter of the independent learning process for students, given that various things are not always controlled like usual learning, students are required to be able to manage themselves, especially their learning schedules during learning that are not normal as usual. Of the several pesantren that carry out this online learning, one of them uses the management's work system as a substitute for controlling parents at home because in the pesantren the situation is very different from the situation in their home where everything can be facilitated. This is a new challenge for pesantren to be able to implement things that must be equivalent to online learning at home with facilities that are completely as-is and are even quite deficient. Therefore, there is a need for management intervention in completing online learning facilities as appropriate, as well as being a controller for students in online learning.

\section{The Role of Foster Caregivers}

In the educational process, several important elements must be present in education, namely the existence of teachers, students, curriculum and facilities. Apart from these 4 things, other things trigger success in education, namely the care of students. This is sometimes something that is often ignored by most people. If we remember that success in education is not only obtained in the realm of the school environment, but also from the family and social environment. So the parenting process is something that cannot be ignored. The parenting process can be the main thing, given that the learning hours done by students at school are not more than the hours of students at home, which will be an exercise to strengthen the character of students.

Learning parenting is the interaction between children and parents during parenting activities in educating children (Harianti and Amin 2016). Parenting is a collection of several models or forms of changes in parental expression to influence the genetic potential that exists in each individual as a form of an effort to maintain, care for, nurture, guide, foster and educate the individual from a child or 
an immature person with the aim that become an independent adult in the future. Education is a form of parenting by helping students in the development of physical and psychological aspects as an effort to internalize the values carried out in educational situations (Anisa 2011). If we look deeper, the meaning of parenting has a more specific meaning, especially for foster caregivers. The carer who is the subject of the parenting style is someone who implements or applies the parenting style.

The meaning of foster care is related to the word nurture or provide guidance and direction. The word foster comes from the same 3 vocabularies, namely asah-asihasuh. Sharpening is honing which means exercising the potential in foster children. Asih, which means loving and full of affection. While caring is caring which is defined as caring for, educating, looking after, guiding, leading and so on (Agus $\mathrm{R}$ and Aliah 2020). It can be concluded that foster care is someone who educates and guides individuals in exercising their potential, both psychologically and physically, with a sense of responsibility, belonging and affection.

From this understanding, pesantren also have a very big role in nurturing and shaping the attitudes of students, so that students can become independent, disciplined, confident and responsible. Thus the institutions in pesantren have the aim that their students become individuals who can think positively so that their attitudes are transmitted in all respects, both in the form of vertical relationships (with God) and horizontal relationships (with others) and to help students develop optimally including physical, psychic, spiritual and psychosocial potential (Lubis 2018). Santri who are accustomed to being given good spiritual and physical guidance will become independent students in all matters and daily life.

The parenting style in the pesantren has its meaning, namely the method or method adopted by the pesantren in educating, guiding, and caring for its students as a manifestation of the pesantren's sense of responsibility to the santri and santri guardians who submit their daughters to the pesantren, by training the quality characteristics of the students compared to students in general. This character education is the main goal to create future generations who are not only able to master their intellectual intelligence (IQ) but also be able to master their emotional and spiritual intelligence (EQ and SQ). 2 ways occur in parenting in pesantren, namely 1) Direct way of 
educating means forms of pesantren care that are related to the formation of personality, intelligence, and skills that are carried out deliberately in the form of orders, prohibitions, punishments for those who violate the rules, or giving gifts to students who get achievements and are usually wrapped in institutions or education at the pesantren. 2) Indirect way of educating is an example of everyday life both in words, attitudes, and tools for habits and patterns of life. Relationships with fellow hut caregivers, cottage officials, the community, fellow santriwati, have accidentally formed a situation of maturity and characteristics of the santriwati themselves, always reflecting on what they see and do every day (Rizqi 2016). The second method is commonly called oral matter, namely teaching through daily actions.

The most important aspects of parenting are acceptance and control. Acceptance is all forms of encouragement, support and affection given to students, while control is the supervision of all student activities. It is the basic duty for foster caregivers to always provide support and direction to the decisions chosen by the students as well as supervise and control the overall activities of the students (Fawaid and Hasanah 2020). From these two aspects, the foster caregivers' control over all activities carried out by their foster children. It is not wrong if foster careers at the pesantren have an important role and become one of the factors in the success of students in education. In addition to this, the role of foster care in the pesantren as a substitute for parents in the dormitory has a significant role, because it continues to set an example according to religious rules (Farhan and Aziah 2019).

The purpose of the guardianship system is to assist students in developing three aspects of learning according to Bloom. In the cognitive aspect, it can be measured through the learning development of students. Meanwhile, in the affective and psychomotor aspects, it is not obtained through their understanding of learning, but can be obtained outside the learning process (Bali and Rohmah 2018). Foster caregivers take a single role in the daily lives of their foster children both inside and outside the learning process. As explained in the previous paragraphs, the life of a foster caregiver in a pesantren does not escape from caring for their foster children, from minor things such as contracting students to every activity of the pesantren to major things that are directly related to the santri guardians and the pesantren caretakers. Naturally, foster 
caregivers know better the santri guardians than other pesantren administrators.

Pesantren teaches that the most important thing in education is not about something that is directed towards cognitive training alone, such as the problem of students who are merely skilled at answering questions or awards for children who can answer exam questions. The most important thing in education is related to teaching. The term teaching (teaching) which in Arabic is called ta'lim and in English teaching is roughly the same meaning as education, namely tarbiyah in Arabic and education in English. In a more ideal sense, teaching even contains the connotation of guiding and helping to facilitate students in undergoing their process of change, namely the learning process to achieve comprehensive and complete creativity, feeling, and intention skills (Ichsan 2016). The basis of pesantren education is education that is more focused on religious education. Education that does not only focus on material alone but also teaches students in the application of the knowledge they get teaches that the most important thing in education is not saving material which is only stored without being practised. This is in line with the application of character education that has been implemented by Indonesian education

Character education requires a process of understanding, planting values, and habituation so that a student loves good deeds. Character is not formed instantly but must be trained seriously and proportionately to achieve ideal form and strength (Adian Husaini 2010). This is where foster caregivers play a greater role because they are related to the nature and daily life of their foster children. In the process of instilling character values, during the learning activities, students cannot be separated from those whose names are being assisted, therefore foster caregivers can become facilitators who organize and provide for the needs of their foster children during the learning process. This is a parenting style, especially in learning activities. Because in essence parenting is always side by side and cannot be separated from education. So that parenting has an important role that especially plays a role in students in education.

\section{METHOD}

This type of research used by researchers is field research with qualitative descriptive research analysis. The purpose of this study is to describe 
online learning held in pesantren. Online learning referred to in this study is learning that uses learning media that can be accessed using internet services such as WhatsApp Group media.

Data collection was carried out by observation and interviews. In making observations, researchers go directly to the field to observe related things that occur at the research location. Researchers also involve themselves in several roles at the research location, ranging from nonparticipants to complete participants. While in the interview process the researcher conducted face to face interviews with participants, the interviews conducted by researchers were open-ended which was designed to bring out the views and opinions of the participants (Creswell 2012). The aspects that are asked in the interview are: (1) The facilities and infrastructure provided by the management to carry out online learning; (2) The response of Tarbiatul Mubtadiat's caregiver regarding the effectiveness of online learning; (3) The mechanism for implementing online learning in the pesantren environment. Researchers are the key instrument in research.

The location that became the object of the researcher was the Fathimatuzzahro area 'Pondok Pesantren Nurul Jadid, especially in the Tarbiatul Mubtadiat boarding house which is the dormitory of Madrasah Ibtidaiyah Nurul Mun'im students who carry out online learning. It was noted that the number of students who conducted online was 12 students and were accompanied by their guardians as many as 5 people, the researchers also included interviews from pesantren administrators as supervisors of the Tarbiatul Mubtadiat hostel and regional heads in adopting online learning systems at pesantren.

\section{RESULT \& DISCUSSION}

\section{Findings}

From the results of observations and interviews of researchers, it was found that online learning carried out in pesantren was a learning solution from the Madrasah Ibtidaiyah Nurul Mun'im educational institution because at this time formal institutions could not carry out activities as usual. According to one teacher at Madrasah Ibtidaiyah Nurul Mun'im, online learning was carried out using the WhatsApp Group media. This is because seeing the condition of society from an economic perspective as well as being underdeveloped in the field of communication and information technology as well as students with santri status who are very limited in internet 
services, WhatsApp is a solution that is expected so that it does not make it difficult for all parties (Aini, Personal interview, 29 October 2020).

There were 12 students with the status of students who were gathered in one hostel, namely the Tarbiatul Mubtadiat hostel. This research is more focused on the student guardianship system, especially in making online learning effective in pesantren. There are 5 foster caregivers in the Tarbiatul Mubtadiat hostel. Each foster caregiver has 2-3 students as foster children. It is noted that the 12 santri who live in the Tarbiatul Mubtadiat dormitory consist of various grade levels, namely 8 students of class VI Madrasah Ibtidaiyah, 3 students of class $\mathrm{V}$ Madrasah Ibtidaiyah and 1 santri of class I Madrasah Ibtidaiyah.

The location in the online learning process is located in the Laptop Area (LA) room. Meanwhile, the online learning mechanism that is implemented is using voice notes and chats with the following KBM arrangement: 1) Opening and attendance. 2) Teaching and Learning Activities which contains; a) Introduction to lessons (voice), b) Reading books, c) Explanation (voice), d) Understanding the material and e) Questions and answers. 3) Closing which is filled with assignments and motivation. Meanwhile, the infrastructure provided by the pesantren uses wifi, laptops and projectors. The requirements and conditions are that it requires 3 laptops with wifi facilities from the regional office. Each level is facilitated by 1 laptop, while specifically for class VI with 8 students, using 1 laptop and projector so that they can be used together (Aisyah, Personal interview, 3 November 2020).

\section{Discussion}

The Fathimatuzzahro area is one of the satellite areas under the auspices of the Pondok Pesantren Nurul Jadid which is located in the Karanganyar Paiton Village, Probolinggo. This region is the only area that has a santri hostel for Madrasah Ibtidaiyah students, namely the Tarbiatul Mubtadiat hostel. For an pesantren which is one of the major pesantren, all pesantren work programs cannot be effective only at the central pesantren, several programs are specialized and implemented in each area of the pesantren, one of which is the guardianship program which is under the coordination of the Pondok Pesantren Nurul Jadid Guidance and Counseling. Following the provisions and instructions issued by the Pondok Pesantren Nurul Jadid regarding guardianship, specifically in the Fathimatuzzahro area, the program is 
under the coordination of the Regional and Dormitory Guidance which is none other than the Regional Guidance and Counseling.

The Fathimatuzzahro area is classified as an area that has less capacity for students than other areas. It is recorded that the total number of students is 259 with 18 foster caregivers for public rooms (junior and senior high school students) and 5 foster caregivers for special dormitories, namely Tarbiatul Mubtadiat hostel (Madrasah Ibtidaiyah student). This data is following the pedatren data (management of pesantren data) obtained from the official pesantren web application (Bali and Rohmah 2018).

Judging from various aspects, from the age point of view to the psychology of Madrasah Ibtidaiyah students, basically it does require special care. Given that the childish nature of Madrasah Ibtidaiyah students who should still be with and spoil their parents is a major challenge for the foster caregivers who take care of them. This test the patience and patience of the foster caregivers to stay with their foster children. therefore for the guardian of Tarbiatul Mubtadiat dormitory is set apart in one hostel.

The term foster caregiver in a pesantren is defined not only as a board member who carries out the duties/activities of the pesantren, but the responsibility of the carer exceeds that of an ordinary administrator, because he sees the extravagant and daily performance even at all times. Foster caregivers have to care for, foster, educate, control and care for their foster children as badals of the parents of students in their homes. As with the duties of parents, foster caregivers play an important role in the daily lives of the students, from waking up to sleeping again, from the aspect of eating to studying, especially the student guardian who is an MI student. This is one of the supports and encouragement for the Tarbiatul Mubtadiat boarding students. As stated by Fawaid and Hasanah in their research, the pesantren environment becomes an environment that plays an important role for the students in shaping character. Thus, the existing parenting style in the pesantren must have a fairly good system in directing and guiding the students (Fawaid and Hasanah 2020).

Online learning is located in the Fathimatuzzahro Laptop Area room, accompanied by carers for each level. Foster caregivers not only assist students when assignments, but also accompany students from the start of online learning until the teaching and learning activities 
are finished. Previous research explained that the assignment system carried out in online learning was monitoring from the teacher/teacher accompanied by coordination with parents, either through video calls or by showing photos of children's learning at home as a form of teacher and parent interaction (Baharun et al. 2020). This can be embraced at once in the guardianship system in pesantren. Tarbiatul Mubtadiat Dormitory Supervisor explained that in the boarding school, the guardian of foster care controls the students during the learning process. Seeing that the current learning process is not face-to-face as previously described and the limited coordination of foster care with the teacher/teacher adds to the extra duty of foster care in taking care of their foster children to be more serious about learning. This makes the foster caregivers not only badal parents but also badals of the teacher/teacher as educators (Fitriyah, Personal interview, 3 November 2020).

During the learning process, the foster caregivers as badal of the teacher/teacher have the responsibility not only for the process of delivering educational material to their foster children, but also should be a facilitator who makes learning easier and as a motivator in arousing the enthusiasm for learning of their foster children. During the learning process, foster caregivers are required to be able to regulate the learning atmosphere of their foster children so that it is fun and not boring. Therefore, foster caregivers have a big influence on the success of learning activities, especially in online learning.

The extra performance of foster caregivers, especially in educating and caring for students, will be a value that becomes uswah for the students they care for. Judging from the study time and daily activities of students, between the time studying at school and the daily activities of the students at the pesantren, it is found that the students have more time while in the pesantren. Thus learning while in pesantren is not an excuse or obstacle for students in the educational process. Even in the lightest conditions, the attitude and behaviour of the foster caregiver will become a role model without being intended by the carer to become a moral teaching that can be imitated by students as observers every day. According to the head of the region, Fathimatuzzahro the daily care of the foster caregivers, from the preparations made for online learning to accompanying students in online learning, has its lesson for the students they care for. This condition indirectly teaches and accustoms students to the behaviors they 
can emulate. The duties of the pesantren which are service as foster care roles are the main teaching that cannot be obtained through theory in learning. Indirectly, foster caregivers carry out three tasks at the same time as boarding school, namely service, education and teaching that cannot be done by other pesantren administrators (Zahro, Personal interview, 5 November 2020).

\section{E. CONCLUSION}

Based on the research results, it can be concluded that foster caregivers have a role that is quite urgent and influential in the lives of students while in the pesantren. Especially for santri who are still in Madrasah Ibtidaiyah school, which in principle need special handling from foster caregivers. Seeing from a psychological point of view, students who are under 11 years of age are individuals who still prefer to play rather than do serious things, it is not surprising that foster caregivers become badals of their parents, they must have extra patience and patience. In online learning, foster caregivers do not only act as badal for the parents but also as badal for the teacher/teacher of their foster children. Because seeing learning that is not face-to-face, the control of learning that is usually carried out by a teacher is transferred to the foster caregivers. Not only in terms of chatting, foster caregivers also have a role as facilitators for students in their daily lives, especially in online learning. Given that they have not been able to carry out all activities independently, thus the willingness of foster care is the most important thing in the effectiveness of students' activities, especially in online learning. This proves that the role of foster caregivers is a central point for the activities of foster children while in pesantren, especially in online learning which needs to be optimized. However, this becomes a meaningful lesson for the students, the patience and patience of foster caregivers in educating their foster children without a doubt will be the inculcation of character values in the students they care for. All functions of the pesantren that not all administrators can do are easy things that can be done by foster caregivers.

\section{DAFTAR PUSTAKA}

Adian Husaini. (2010). Pendidikan Islam: Membentuk Manusia Berkarakter. XXVI. Jakarta: Cakrawala Publishing.

Agus R, Abu Hasan, and Firdausul Jannatul Aliah. (2020). Reinforcement Furudul 'Ainiyah Santri Melalui Intensifikasi Wali Asuh Di Pondok Pesantren Nurul Jadid." Islamika 2 (2): https://doi.org/10.36088/islamika.v2i2. 
797.

Anisa, Ani Siti. (2011). Pola Asuh Orang Tua Dan Implikasinya Terhadap Pembentukan Karakter Anak." Jurnal Pendidikan Universitas Garut 5 (1): 70-84.

Anisah Bahyah Ahmad. (2006). Sejarah Pendidikan Pada Zaman Rasulullah S.a.w.

Baharun, Hasan, Muhammad Mushfi El Iq Bali, Chusnul Muali, and Laili Munawaroh. (2020). Self-Efficacy Sebagai Media Peningkatan Profesionalisme Guru Di Madrasah. Risalah: Jurnal Pendidikan Dan Studi Islam 6(1): 244-57.

Bali, Muhammad Mushfi El Iq. (2017). Perguruan Tinggi Islam Berbasis Pondok Pesantren. AL-TANZIM $\square$ : Jurnal Manajemen Pendidikan Islam, 1(2): $1-14$. https://doi.org/10.33650/altanzim.v1i2.109.

Bali, Muhammad Mushfi El Iq. (2019). Implementasi Media Pembelajaran Berbasis Teknologi Informasi dan Komunikasi dalam Distance Learning. Tarbiyatuna: Kajian Pendidikan Islam, 3(1): 28-38.

Bali, Muhammad Mushfi El Iq, and Moh. Fajar Sodik Fadli. (2019). Implementasi Nilai-Nilai Pendidikan Pesantren dalam Meningkatkan Ketahanan Mental Santri. PALAPA: Jurnal Studi Keislaman dan Ilmu Pendidikan, $\quad 7(1)$ : 1-15. https://doi.org/10.36088/palapa.v7i1.1 64.

Bali, Muhammad Mushfi El Iq, and Lailatul Rohmah. (2018). Implementasi Pendekatan Eklektik Berbasis Sharing Zone. Murobbi: Jurnal Ilmu Pendidikan, 6(2): 152-67. http://jurnal.iaibafa.ac.id/index.php/m urobbi/article/view/143.
Bali, Muhammad Mushfi El Iq, and Susilowati. (2019). Transinternalisasi Nilai-Nilai Kepesantrenan Melalui Konstruksi Budaya Religius di Sekolah. Jurnal Pendidikan Agama Islam, 16(1): 1-12. https://doi.org/10.14421/jpai.2019.161 -01 .

Creswell, John W. (2012). Educational Research: Planning, Conducting, and Evaluating Quantitative and Qualitative Research. PEARSON. 4thed. Boston: Pearson Education, Inc. https://doi.org/10.1017/CBO97811074 15324.004 .

Dewi, Wahyu Aji Fatma. (2020). Dampak COVID-19 Terhadap Implementasi Pembelajaran Daring Di Sekolah Dasar. Edukatif $\square$ : Jurnal Ilmu Pendidikan, 2(1): 55-61. https://doi.org/10.31004/edukatif.v2i1. 89.

Farhan, and Aziah. (2019). Upaya Wali Asuh Pada Peserta Asuh Mematasi Bulliying di Pesantren Nurul Jadid Perspektif Komunikasi Persuasif. Briliant, 53(9): 1689-99.

Fawaid, Achmad, and Uswatun Hasanah. (2020). Pesantren dan Religious Authoritative Parenting: Studi Kasus Sistem Wali Asuh di Pondok Pesantren Nurul Jadid. Jurnal Ilmiah Ilmu Ushuluddin, 19 (1): 27. https://doi.org/10.18592/jiiu.v19i1.348 4.

Harianti, Rini, and Suci Amin. (2016). Pola Asuh Orangtua dan Lingkungan Pembelajaran Terhadap Motivasi Belajar Siswa. Curricula, 2(2): 20-30. https://doi.org/10.22216/jcc.v2i2.983.

Ichsan, Muhammad. (2016). Psikologi Pendidikan Dan Ilmu Mengajar. JURNAL EDUKASI: Jurnal Bimbingan Konseling, 2(1): 60. https://doi.org/10.22373/je.v2i1.691. 
Ilmy, Alfi Najmatil, Abd Hamid Wahid, and Chusnul Muali. (2018). Pendidikan di Pesantren. Pendidikan Agama Islam: Journal of Islamic Education Studies, 6(1): 45.

Islam, Syaiful, Hasan Baharun, Chusnul Muali, Moh Idil Ghufron, Muhammad Mushfi El Iq Bali, Mualim Wijaya, and Ismail Marzuki. (2018). To Boost Students' Motivation and Achievement through Blended Learning. In Journal of Physics: Conference Series, 1114:1-11. Institute of Physics Publishing. https://doi.org/10.1088/17426596/1114/1/012046.

Khusniyah, Nurul Lailatul, and Lukman Hakim. (2019). Efektivitas Pembelajaran Berbasis Daring: Sebuah Bukti Pada Pembelajaran Bahasa Inggris. Jurnal Tatsqif, 17(1): 19-33. https://doi.org/10.20414/jtq.v17i1.667.

Lubis, Rafiqatul Hamidiyah. (2018). Metode Parenting Pembentukan Ssikap Santri di Pondok Pesantren Modern Darussalam Kepahiang, Bengkulu." In .

Mashudi.( 2020). Pesantren -Based Higher Education Institutions $\square$ : The Format of Modern Islamic Education. Ta'dib: Jurnal Pendidikan Islam, 25(2): 11935. https://doi.org/ISSN $\square: 2443-2512$.

Muali, Chusnul, Syaiful Islam, Muhammad Mushfi El Iq Bali, H. Hefniy, Hasan Baharun, Akmal Mundiri, Moh Jasri, and Ahmad Fauzi. (2018). Free Online Learning Based on Rich Internet Applications; The Experimentation of Critical Thinking about Student Learning Style. In Journal of Physics: Conference Series, 1114:1-6. Institute of Physics Publishing. https://doi.org/10.1088/17426596/1114/1/012024.

Munif, Muhammad, and Siti Aisah. (2020). Six Medicine Qoulan Dalam
Mengatasi Kekerasan Guru Terhadap Siswa di Lembaga Pendidikan. Jurnal Inspiratif Pendidikan, IX(2): 35-52.

Nurkholis. (2013). Pendidikan dalam Upaya Memajukan Teknologi. Jurnal Kependidikan, 1(1): 24-44.

Oktavia, Dewi, Muhammad Mushfi El Iq Bali, Handono Rahman, Umar Umar, Agus Syakroni, and Faizatul Widat. (2019). Exploration of Fine Motor Skills through the Application of Paint. In WESTECH, 1-6. European Alliance for Innovation n.o. https://doi.org/10.4108/eai.8-122018.2284038 .

Rahman, Arif, and Dkk. (2020). Problematika Pendidikan Islam di Era Revolusi Industri 4.0. Jurnal Pendidikan Islam. Vol. 9. https://doi.org/10.38073/jpi.v9i1.204.

Rahman, Kholilur, Abdul Wahid, Irfan Afandi, Muhammad Mushfi El Iq Bali, and Lukman Hakim. (2019). Effectiveness of Teams TeachingHybrid Learning (TTHL) in Higher Education. In WESTECH, 1-6. European Alliance for Innovation n.o. https://doi.org/10.4108/eai.8-122018.2284036 .

Rizqi, Amalina. (2016). Hubungan Pola Asuh Pondok Pesantren Dengan Pembentukan Karakter Santriwati," no. August.

Rozi, Fathor, Muhammad Mushfi El Iq Bali, Sulton Firdaus, Muallim Wijaya, Rahmatul Aziz Al Mursyidi, Moh Wasil Haqiki, and Zainal Abidin. (2020). Learning Management; Identifying Learning Styles of Language Learners in Madrasah. Proceedings of the International Conference on Industrial Engineering and Operations Management 5 (August): 3783-90.

Sadikin, Ali, and Afreni Hamidah. (2020). 
Pembelajaran Daring di Tengah WabahCovid-19 (Online Learning in the Middle of the Covid-19 Pandemic). BIODIK: Jurnal Ilmiah Pendidikan Biologi, 6(2): 187-92.

Sugiyono, Samijo, Sutopo, and Apri Nuryanto. 2014. "Pendidikan Beretika Dan Berbudaya," 1-143.

Wahid, Abd Hamid, Najiburrahman, Kholilur Rahman, Faiz, Khodijatul Qodriyah, Hambali, Muhammad Mushfi El Iq Bali, Hasan Baharun, and Chusnul Muali. (2020). Effectiveness of Android-Based Mathematics Learning Media Application on Student Learning Achievement." In Journal of Physics: Conference Series, 1-7. IOP Publishing. https://doi.org/10.1088/17426596/1594/1/012047.

Yoga Purandina, I Putu, and I Made Astra Winaya. (2020). Pendidikan Karakter di Lingkungan Keluarga Selama Pembelajaran Jarak Jauh Pada Masa Pandemi COVID-19. Cetta: Jurnal Ilmu Pendidikan, 3(2): 270-90. https://doi.org/10.37329/cetta.v3i2.454

Zamroni, Hasan Baharun, Hefniy, Muhammad Mushfi El Iq Bali, and Kusmiyatun Hasanah. (2020). Leader Member Exchange Dalam Membangun Komunikasi Efektif di Pondok Pesantren. El-Buhuth: Borneo Journal of Islamic Studies, 3(1): 7789. 
